\title{
OPTIMALISASI BREAST FEEDING PADA IBU NIFAS 0-3 HARI DI RUMAH SAKIT AWAL BROS A.YANI
}

\author{
Elvi Murniasih ${ }^{1}$, Rita Mulyani ${ }^{2}$ \\ ${ }^{1,2)}$ STIKes Awal Bros Batam \\ email: elvi.murniasih77@gmail.com, Ritamuliani12@gmail.com
}

\begin{abstract}
Abstrak
Asi eksklusif sangat direkomendasikan oleh American Academy of Pediatrics kepada bayi selama 6 bulan. ASI merupakan nutrisi terbaik secara khusus di tunjukan bagi bayi baru lahir. Karena mengandung berbagai komponen antibiotik, nutrisi yang lengkap dan mudah dicerna oleh bayi baru lahir dibandingkan dengan susu formula. Adapun tujuan setelah mendaptkankan penyuluhan teknik menyusui, diharapkan peserta ibu nifas 0-3 hari di Rumah Sakit Awal Bros A. Yani dapat menyusui dengan baik dan benar. Adapun kegiatan yang dilakukan berupa penyuluhan teknik yang benar sesuai standar operasional prosedur. Hasil yang di harapkan dari pengabdian masyarakat ini, ibu nifas di Rumah Sakit Awal Bros A. Yani mampu melakukan redemonstrasi teknik menyusui yang baik dan benar.
\end{abstract}

Kata Kunci : Teknik menyusui, ibu nifas, ASI eksklusif

\begin{abstract}
Exclusive breastfeeding is highly recommended by the American Academy of Pediatrics to babies for 6 months. Breast milk is the best nutrition specifically shown for newborns. Because it contains various antibiotic components, it is nutritionally complete and easily digested by newborns compared to formula milk. As for the goal after getting counseling on breastfeeding techniques, it is hoped that the participants of 0-3 days postpartum mothers at Awal Bros A. Yani Hospital can breastfeed properly and correctly. The activities carried out were in the form of correct technical counseling according to standard operating procedures.mThe expected results from this community service, postpartum mothers at Awal Bros A. Yani Hospital were able to redemonstrate proper and correct breastfeeding techniques.
\end{abstract}

Keywords: Breastfeeding Technique,Postpartum Mother, Exclusive Breast Feeding

\section{PENDAHULUAN}

WHO dan UNICEF merekomendasikan pemberian nutrisiyang optimal bagi bayi baru lahir yakni melalui strategi global pemberian ASI eksklusif selama enam bulan (WHO, 2017). America Academy of Pediatrics merekomendasikan pemberian ASI eksklusif kepada bayi selama minimal 6 bulan dan dapat dilanjutkan minimal sampai bayi berusia 12 bulan. ASI merupakan nutrisi terbaik yang secara khusus ditujukan bagi bayi baru lahir karena mengandung berbagai komponen antibodi, nutrisi yang lengkap dan mudah dicerna oleh bayi baru lahir dibandingkan dengan susu formula. (Perry 2010)

Selain memiliki manfaat bagi bayi, proses menyusui juga memiliki manfaat yang besar bagi ibu setelah melahirkan. Proses menyusui dapat mencegah perdarahan pasca persalinan karena kontraksi uterus yang dirangsang oleh hormon oksitosin, mempercepat involusi uterus, mengurangi risiko terjadinya anemia, mengurangi risiko kanker ovarium dan payudara, memberikan rasa dibutuhkan, memperkuat ikatan batin seorang ibu dengan bayi yang dilahirkan, mempercepat kembali ke berat badan semula, dansebagai salah satu metode kontrasepsi sementara (Astutik, 2014).

Berdasarkan hal tersebut, pengabdian masyarakat ini dilakukan bertujuan untuk mengajarkan bagaimana cara teknik menyusui yang benar untuk pemberian ASI ekskulusif pada bayidi Rumah Sakit Awal Bros A. Yani.

\section{METODE}

Adapun sasaran dalam kegiatan pengabdian masyarakat ini adalah ibu nifas 0-3 hari di Rumah Sakit Awal Bros A. Yani. Metode yang digunakan dalam kegiatan penyuluhan dilakukan dengan tiga 
macam, yaitu : metode ceramah, diskusi,tanya jawab dan praktik cara teknik menyusui. Kegiatan ini di awali dengan pengenalan pentingnya pemberian ASI eksklusif.

\section{HASIL DAN PEMBAHASAN}

1. Tahap persiapan

Melakukan koordinasi dengan diklat Rumah Sakit Awal Bros A.Yani yang dilakukan pada tanggal 05 Oktober 2020 dari hasil koordinasi tersebut disepakati untuk melakukan kegiatan sosialisasi dengan pasien ibu post partum Rumah Sakit Awal Bros A. Yani.

2. Tahap Implementasi

Pelaksanaan kegiatan ini dilaksanakan pada 6 Oktober 2020, dengan Ibu nifas 0-3 hari menhadi responden Rumah Sakit Awal Bros A. Yani Dengan di ikuti 10 responden. Saat penyampaian materi peserta mampu mengulang kembali materi yang di sampaikan, narsumber sangat interaktif selama kegiatan berlangsung.

3. Tahap Evaluasi

Evaluasi dari kegiatan ini dilakukan dengan mengajarkan teknik memberikan ASI ekskuisif .
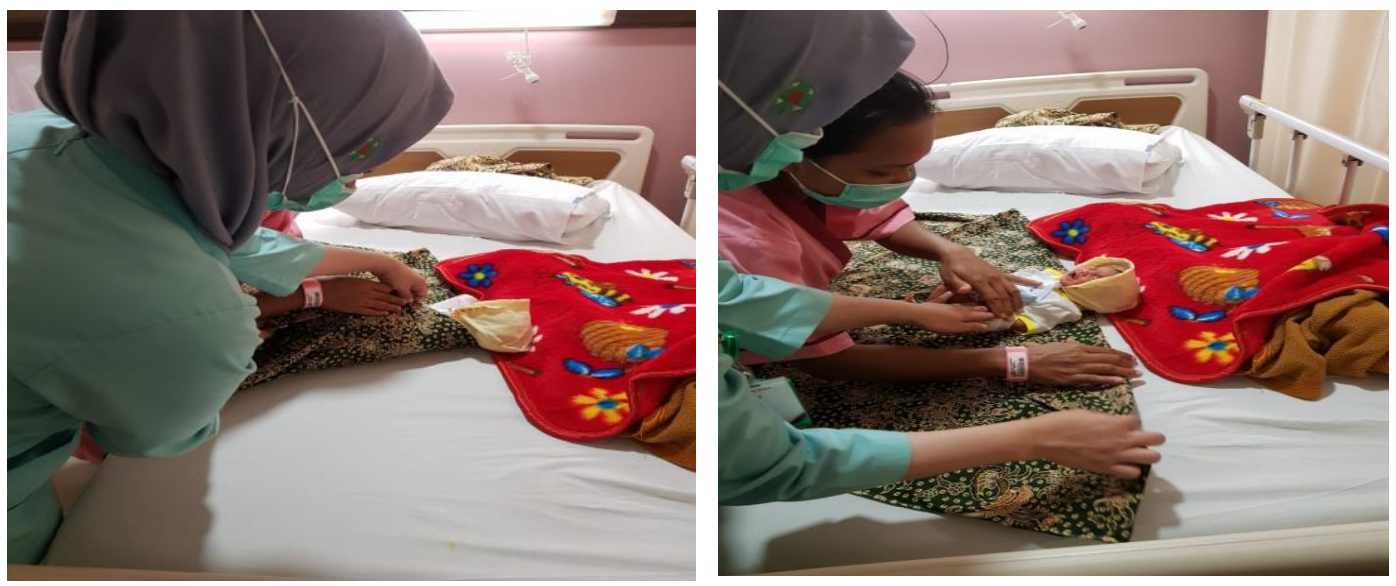

Gambar 1. Menjelaskan Teknik Menyusui ASI eksklusif

\section{SIMPULAN}

Kesimpulan dari pengabdian masyarakat ini adalah bahwa pentingnya pemberian teknik ASI eksklusif pada bayi sangatlah baik untuk bayi mendapatkan nutrisi yang cukup. Dimana ASI merupakan makan yang sangat mengandung gizi.

\section{UCAPAN TERIMA KASIH}

Pengabdi mengucapkan terimakasih kepada Rumah Sakit Awal Bros A.Yani sebagai mitra pengabdian Masyarakat yang sudah bersedia berkerjasama dalam pelaksanaan pengabdian kepada masyarakat ini.

\section{DAFTAR PUSTAKA}

Astutik, Reni Yulia. (2014). Payudaradan Laktasi. Jakarta : Salemba Medik.

Dinas kesehatan ProvinsiLampung (2016). Profil kesehatan provinsi lampung.

Dinas kesehatan Provinsi Lampung, (2017). Profil Dinas Kesehatan Kabupaten Lampung Utara 2017. Kementerian kesehatan Republik Indonesia, (2016). Buku Kesehatan Ibu Dan Anak. Kementrian

Kesehatan Ri Dan Jica. Jakarta.

Kementrian Kesehatan, Republik Indonesia, (2017). Data dan Informasi Profil Kesehatan Indonesia tahun 2016. Kementrian Kesehatan Republik Indonesia, Pusdatin Kemenkes RI

Perry, E. Shannon., Hockenberry, J.M., Lowdermilk, L.D., Wilson. D. (2010).MaternalChild Nursing

Care 4th Edition. St. Louis : Mosby-Elsevi.Yuliarti, N. (2010). Keajaiban ASI makanan terbaik untuk kesehatan, kecerdasan dan kelincahan si kecil. Penerbit Andi

WHO. Infant and Young Child Feeding: Model Chapter for Textbooks for Medical Students and Allied Health Professionals.[Online] 2017[diakses 28 November 2017]. Available at :https://www.ncbi.nlm.nih.gov/books/NBK148955/\#_session7_s9 